\title{
PHYLOGENETIC RELATIONSHIPS AMONG CALLOSCIURUS SQUIRRELS IN THE INDOCHINA PENINSULA: PHYLOGENETIC POSITION OF C. PYGERYTHRUS FROM MYANMAR
}

\author{
Tatsuo Oshida ${ }^{1}$, Wynn Than ${ }^{2}$, Thida Oo ${ }^{2}, K_{\text {hin }}$ Yu Yu Swe ${ }^{3}$ \\ Hiroaki Saito ${ }^{4}$, Masaharu Motokawa ${ }^{5}$, Junpei Kimura ${ }^{6}$, Son Truong Nguyen ${ }^{7}$ \\ Hai Tuan Bui ${ }^{8}$ and Phuong Huy Dang ${ }^{9}$
}

\begin{abstract}
${ }^{1}$ Laboratory of Wildlife Ecology, Obihiro University of Agriculture and Veterinary Medicine Obihiro 080-8555, Japan; E-mail: oshidata@obihiro.ac.jp; https://orcid.org/0000-0003-0863-9530 ${ }^{2} Z$ Zoology Department, West Yangon University, Httantabin Township, Yangon 11401, Myanmar;

E-mails: dennniswynn@gmail.com, https://orcid.org/0000-0002-2236-8899 prof.thidaoo@gmail.com, https://orcid.org/0000-0002-7941-610X

${ }^{3}$ Zoology Department, Mandalar University, Amarapura Township, Mandalay 0561, Myanmar;

E-mail: yuyuswe.dr@gmail.com, https://orcid.org/0000-0001-7417-5952

${ }^{4}$ Graduate School of Science, Kyoto University, Kyoto 606-8501, Japan

E-mail: keiryu.fishing@gmail.com, https://orcid.org/0000-0002-6488-9887

${ }^{5}$ The Kyoto University Museum, Kyoto University, Kyoto 606-8501, Japan

E-mail:motokawa@e23.jp,https://orcid.org/0000-0002-5359-0070

${ }^{6}$ Seoul National University, Seoul 151-742, Korea

E-mail: jay.kimura@me.com, https://orcid.org/0000-0003-3130-9716

${ }^{7}$ Department of Vertebrate Zoology, Institute of Ecology and Biological Resources

Vietnam Academy of Science and Technology, 18 Hoang Quoc Viet Street, Hanoi, Vietnam

E-mail: truongsoniebr@gmail.com, https://orcid.org/0000-0003-3214-4407

${ }^{8}$ Vietnam National Museum of Nature, Vietnam Academy of Science and Technology 18 Hoang Quoc Street, Hanoi, Vietnam

E-mail: tuanhai@eulipotyphla.com,https://orcid.org/0000-0003-4065-7229

${ }^{9} \mathrm{Me}$ Linh Station for Biodiversity, Institute of Ecology and Biological Resources

Vietnam Academy of Science and Technology, 18 Hoang Quoc Street, Hanoi, Vietnam

E-mail: phuongiebr@gmail.com, https://orcid.org/0000-0002-2323-9511
\end{abstract}

The phylogenetic relationships among seven Callosciurus species from the Indochina Peninsula, including the C. honkhoaiensis which is endemic to Hon Khoai Island, were studied using complete mitochondrial cytochrome $b$ gene sequences (1140 bases). We primarily focused on the phylogenetic position of C. pygerythrus, which is distributed in the western part of the peninsula. We identified two main lineages: 1) C. caniceps, C. honkhoaiensis, $C$. inornatus, C. phayrei and C. pygerythrus, and 2) C. erythraeus and C. finlaysonii. Estimated divergence time between the two lineages was at the junction of the Zanclean and Piacenzian in the Pliocene. Within the first linage, the divergence time of sub-lineages corresponded to the Pliocene-Pleistocene boundary, although phylogenetic relationships were unclear. These two divergence times estimated in the present study correspond to episodes of global cooling, suggesting that climate may have contributed to the divergence of these Callosciurus squirrels.

Keywords: cytochrome b, global cooling, Irrawaddy squirrel, Phayre's squirrel. 


\section{INTRODUCTION}

The Indochina Peninsula of Southeast Asia is a biodiversity hotspot (Cox \& Moore 2005, Mittermeier et al. 2011), harbouring many endemic mammals, such as saola (Pseudoryx nghetinhensis), Tonkin snub-nosed monkey (Rhinopithecus avunculuc), Delacour's langur (Trachypithecus delacouri) and southern white-cheeked gibbon (Nomascus siki) (Groves 2005, Grubв 2005). Recently, new bat species (Myotis indochinensis and Murina kontumensis) have been reported from this region (NGUYEN et al. 2013, 2015), further highlighting the importance of this region in understanding the evolutionary forces driving mammalian speciation.

Arboreal squirrels, such as Callosciurus Gray, 1867, are good models to better understanding the patterns of speciation in the Indochina Peninsula because of their high diversity (Oshida et al. 2011). Out of 15 Callosciurus species in Southeast Asia (Koprowski et al. 2016, Nguyen et al. 2018), seven occur in the Indochina Peninsula and adjacent islands: grey-bellied squirrel (C. caniceps (Gray, 1842)), Pallas's squirrel (C. erythraeus (Pallas, 1779)), Finlayson's squirrel (C. finlaysonii (Horsfield, 1823)), Hon Khoai squirrel (C. honkhoaiensis Nguyen, Oshida, Dang, Bui et Motokawa, 2018), Inornate squirrel (C. inornatus (Gray, 1867)), Phayre's squirrel (C. phayrei (Blyth, 1856)) and Irrawaddy squirrel (C. pygerythrus (I. Geoffroy Saint Hilaire, 1833)) (CoRbet \& Hill 1992, Thorington \& Hoffmann 2005, Nguyen et al. 2018). Boonkhaw et al. (2017) reported that species from the Indochina Peninsula form monophyletic group consisting of two major lineages: erythraeus-finlaysonii lineage and canicepsinornatus-phayrei lineage. Furthermore, NGuYen et al. (2018) reported that C. honkhoaiensis, which is endemic to Hon Khoai Island located off the Indochina Peninsula, was closely related to $C$. caniceps.

In the Indochina Peninsula, high divergences of Callosciurus squirrels are recognized. Based on mitochondrial DNA sequences, Oshid et al. (2011) suggested the role of the Mekong River in the divergence of $C$. caniceps and C. inornatus, thus supporting the riverine barrier hypothesis (e.g. SALO et al. 1986, MacKinnon et al. 1996, Meijaard \& Groves 2006, Oshida et al. 2001, 2016), which also explains intra-specific diversity in C. erythraeus (Oshide et al. 2013) and C. finlaysonii (BoonkHAw et al. 2017). BoonkHAw et al. (2017) showed that $C$. erythraeus and $C$. finlaysonii did not form each monophyletic group and that the C. erythraeus/C. finlaysonii complex in Thailand consisted of seven groups. Recently, based on morphological and genetic data, BALAKIREV and RozHnov (2019) explained the inconsistency of the present subspecific classification of the C. erythraeus/finlaysonii complex. These phylogenetic studies on Callosciurus squirrels in the Indochina Peninsula have mainly focused on the species distributed in central and eastern regions. To better understand the evolutionary history of Callosciurus, the species distributed in the western 
part of the peninsula (C. phayrei and C. pygerythrus; Koprowski et al. 2016; Fig. 1) need to be included in the phylogenetic analyses. Although BoonkHAw et al. (2017) reported the close relationship of $C$. phayrei to $C$. caniceps within caniceps-inornatus-phayrei lineage, the phylogenetic position of C. pygerythrus is still unknown.

To examine the phylogenetic position of C. pygerythrus, we investigated the phylogenetic relationships among the seven peninsular Callosciurus species. Callosciurus pygerythrus covers the westernmost area of the distribution of the genus Callosciurus, occurring from central Nepal to Myanmar (CORBET \& Hill 1992). Therefore, this species may be distantly related to others owing to its different evolutionary history. As C. pygerythrus resembles C. caniceps in external morphology (ELLERMAN \& MorRISON-SCOTt 1966), it may be included in the caniceps-inornatus-phayrei lineage proposed by BoonkHAw et al. (2017). Here, we test these phylogenetic hypotheses using mitochondrial DNA (cytochrome $b$ ) sequences and discuss the evolutionary history of Callosciurus, including C. pygerythrus in the Indochina Peninsula.

\section{MATERIAL AND METHODS}

\section{Material}

We examined seven Callosciurus species from the Indochina Peninsula region (C. caniceps, C. erythraeus, C. finlaysonii, C. honkhoaiensis, C. inornatus, C. phayrei and C. pygerythrus), and three from the Sunda region: C. nigrovittatus (Horsfield, 1823), C. notatus (Boddaert, 1785) and C. prevostii (Desmarest, 1822). We collected two C. phayrei and seven C. pygerythrus from Myanmar (Table 1 \& Fig. 1). The genus Lariscus is closely related to Callosciurus (Mercer \& Roth 2003), and hence the three-striped ground squirrel (Lariscus insignis) was used as an outgroup in the phylogenetic analyses. DNA sequence data of L. insignis and the Callosciurus species except for C. phayrei and C. pygerythrus were obtained from the DNA Data Bank of Japan (DDBJ) (Table 1).

\section{Extraction, amplification and sequencing of DNA}

Total genomic DNA of C. phayrei and C. pygerythrus was extracted with the QuiaQuick Kit (QUIAGEN K. K., Tokyo, Japan) from muscle tissue preserved in 99\% ethanol. Complete cytochrome $b$ gene sequences (1140 bases) were amplified with polymerase chain reaction (PCR) using primer set: L14724 5'-GATATGAAAAACCATCGTTG-3' (Kocher et al. 1989) and H15910 5'-GATTTTTGGTTTACAAGACCGAG-3' (OshidA et al. 2000). The $50 \mu \mathrm{l}$ reaction mixture contained $100 \mathrm{ng}$ of genomic DNA, $25 \mathrm{pM}$ of each primer, $200 \mu \mathrm{M}$ dNTPs, $10 \mathrm{mM}$ Tris- $\mathrm{HCl}$ (pH 8.3), $50 \mathrm{mM} \mathrm{KCl}, 1.5 \mathrm{mM} \mathrm{MgCl}_{2}$, and 2.5 units of rTaq DNA polymerase (Takara, Otsu, Japan). Amplification was carried out for 35 cycles using the following cycle program: $94{ }^{\circ} \mathrm{C}$ for $1 \mathrm{~min}, 55^{\circ} \mathrm{C}$ for $1 \mathrm{~min}$, and $72{ }^{\circ} \mathrm{C}$ for $2 \mathrm{~min}$ (Oshids et al. 2011). The extension reaction was completed by incubation at $72{ }^{\circ} \mathrm{C}$ for $10 \mathrm{~min}$. The PCR products were purified with PCR Clean Up-M (Viogen, Taiwan) and directly sequenced using an automated DNA sequencer (ABI PRISM 377-96 Sequencer and ABI PRISM 3100 
Table 1. Squirrels examined in this study and retained in our private collections in the Laboratory of Wildlife Biology, Obihiro University of Agriculture and Veterinary Medicine (indicated by identity numbers beginning with OS). Numbers with species name correspond to those in Fig. 2. HUnknown exact collecting locality. ${ }^{* S a m p l e s ~ c o l l e c t e d ~ i n ~ t h i s ~ s t u d y . ~}$

\begin{tabular}{|c|c|c|c|}
\hline $\begin{array}{l}\text { Species and } \\
\text { haplotype }\end{array}$ & Collecting locality & Identity no. & $\begin{array}{c}\text { Accession } \\
\text { No. }\end{array}$ \\
\hline C. caniceps 1 & Pasoh Forest Res., Negeri Sembilan, Malaysia & Y3 & AB499918 \\
\hline C. caniceps 2 & Pasoh Forest Res., Negeri Sembilan, Malaysia & Y25 & AB499919 \\
\hline C. erythraeus 1 & Tam Dao, Vietnam & 33 & AB499908 \\
\hline C. erythraeus 2 & Tam Dao, Vietnam & 34 & AB499909 \\
\hline C. finlaysonii 1 & Thailandt & OS254 & AB499910 \\
\hline C. finlaysonii 2 & Thailand $t$ & OS255 & AB499911 \\
\hline C. honkhoaiensis 1 & Hon Khoai Island, Vietnam & $\begin{array}{l}\text { HK-2017.31, } \\
\text { HK-2017.44 }\end{array}$ & LC306835 \\
\hline C. honkhoaiensis 2 & Hon Khoai Island, Vietnam & HK-2017.48 & LC306836 \\
\hline C. inornatus 1 & Co Ma, Thuan, Chau, Son La, Vietnam & 183 & AB499905 \\
\hline C. inornatus 2 & Hon, Phu Yen, Son La, Vietnam & 191 & AB499906 \\
\hline C. inornatus 3 & Hon, Phu Yen, Son La, Vietnam & 199 & AB499907 \\
\hline C. nigrovittatus 1 & Pasoh Forest Res., Negeri Sembilan, Malaysia & Y26 & AB499916 \\
\hline C. nigrovittatus 2 & Pasoh Forest Res., Negeri Sembilan, Malaysia & $\mathrm{Y} 28$ & AB499917 \\
\hline C. notatus 1 & Pasoh Forest Res., Negeri Sembilan, Malaysia & Y11 & AB499912 \\
\hline C. notatus 2 & Pasoh Forest Res., Negeri Sembilan, Malaysia & $\mathrm{Y} 12$ & AB499913 \\
\hline C. phayrei & Taungoo, Myanmar & OS822, OS823 & LC552998 \\
\hline C. prevostii 1 & Palembang, Indonesia & OS311 & AB499914 \\
\hline C. prevostii 2 & Palembang, Indonesia & OS312 & AB499915 \\
\hline C. pygerythrus1 & Yangon, Myanmar & $\begin{array}{l}\text { OS786, OS787, } \\
\text { OS788, OS789 }\end{array}$ & LC552995 \\
\hline C. pygerythrus2 & Mandalay, Myanmar & OS806 & LC552996 \\
\hline C. pygerythrus3 & Mandalay, Myanmar & OS807, OS808 & LC552997 \\
\hline Lariscus insignis & Pasoh Forest Res., Negeri Sembilan, Malaysia & Y8 & AB499904 \\
\hline Menetes berdmorei & Cat Tien National Park, Vietnam & OS345(66) & LC552999 \\
\hline
\end{tabular}

Genetic Analyzer Applied Biosystem, CA, US). For sequencing, we used both forward and reverse primers used for PCR. Purification of the PCR products and sequencing were done by Mission Biotech Co. Ltd. (Taipei, Taiwan).

\section{Sequence and phylogenetic analyses}

Sequence alignment to detect unique haplotypes was with the software program dnasis (Hitachi, Tokyo, Japan), followed by phylogenetic analyses in MEGA 7 (Kumar et al. 2016). The Hasegawa-Kishino-Yano (HKY) model (Hasegawa et al. 1985) for nucleotide substitution with the proportion of invariable sites (0.54), and gamma distribution for vari- 
able sites (1.85) $(\mathrm{HKY}+\mathrm{I}+\Gamma)$ was selected based on the Bayesian Information Criterion values, and used for the maximum likelihood (ML) analysis. Additionally, the unweighted maximum-parsimony (MP) analysis with tree-bisection-reconnection and neighbor-joining (NJ) analysis (SAITOU \& NeI 1987) using the genetic distances correlated by the Kimura 2-parameter method (KIMURA 1980) were performed. We assessed nodal supports by bootstrapping (FELSENSTEIN 1985) with 1000 replicates for ML and MP analyses, and 5000 replicates for NJ analysis. Bayesian inference (BI) was performed using BEAST 1.10.4 (SUCHARD et al. 2018) using the HKY + I + $\Gamma$ substitution model, with two runs for ten million steps, using four Markov chain Monte Carlo chains sampling every 1000 steps, and a burn-in of $10 \%$. Posterior probabilities were used to assess the nodal support of the BI tree. Divergence times among the Callosciurus species were estimated using the RelTime method (TAMURA et al. 2012) in MEGA7. The divergence time between Callosciurus and Lariscus (7.5 \pm 1.2 million years ago (Ma); MERCER \& Roth 2003) was used as a calibration point, by including Menetes berdmorei (a sister group to the ancestor of Callosciurus and Lariscus; Mercer \& Rотн 2003) as an outgroup (Table 1).

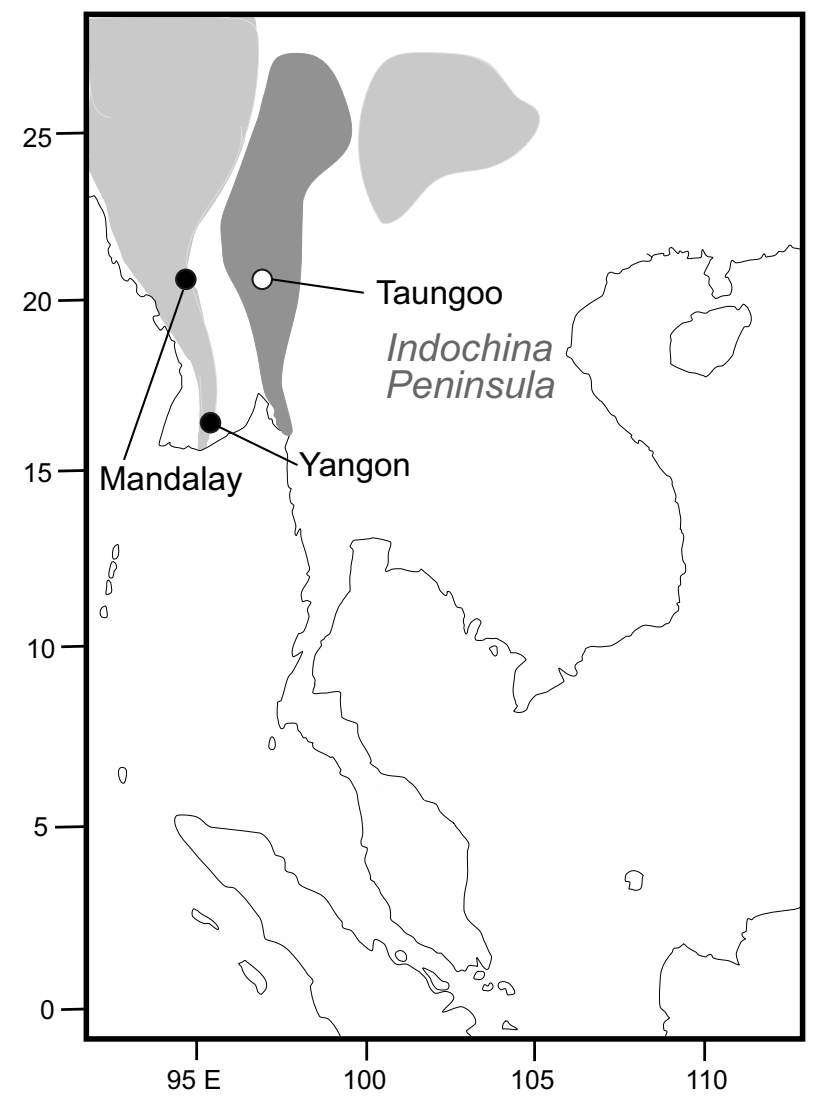

Fig. 1. Distribution of Callosciurus phayrei (dark gray area) and C. pygerythus (light gray area) in the Indochina Peninsula (Koprowski et al. 2016) and collecting sites of squirrels examined in the present study. Open and closed circles indicate C. phayrei and C. pygerythus, respectively 


\section{RESULTS}

Complete sequences (1140 bp) of cytochrome $b$ gene were successfully obtained from two $C$. phayrei and seven C. pygerythrus. All sequences were deposited in the DNA Data Bank of Japan (DDBJ) (Table 1). The ML phylogenetic tree is shown in Fig. 2. The topology of NJ, MP and BI trees was essentially similar to that of ML tree. All trees showed two well-supported lineages, namely the Indochina lineage (C. caniceps, C. erythraeus, $C$. finlaysonii, C. honkhoaiensis, C. inornatus, C. phayrei and C. pygerythrus) and the Sunda linage (C. nigrovittatus and C. prevostii). Within the Indochina lineage, two major lineages were observed, namely linage A (C. caniceps, C. honkhoaiensis, C. inornatus, C. phayrei and C. pygerythrus) and linage B (C. erythraeus and C. finlaysonii). Within the lineage A, we found two sub-lineages: one consisting of $C$. inornatus and C. pygerythus and the other consisting of $C$. caniceps, $C$.

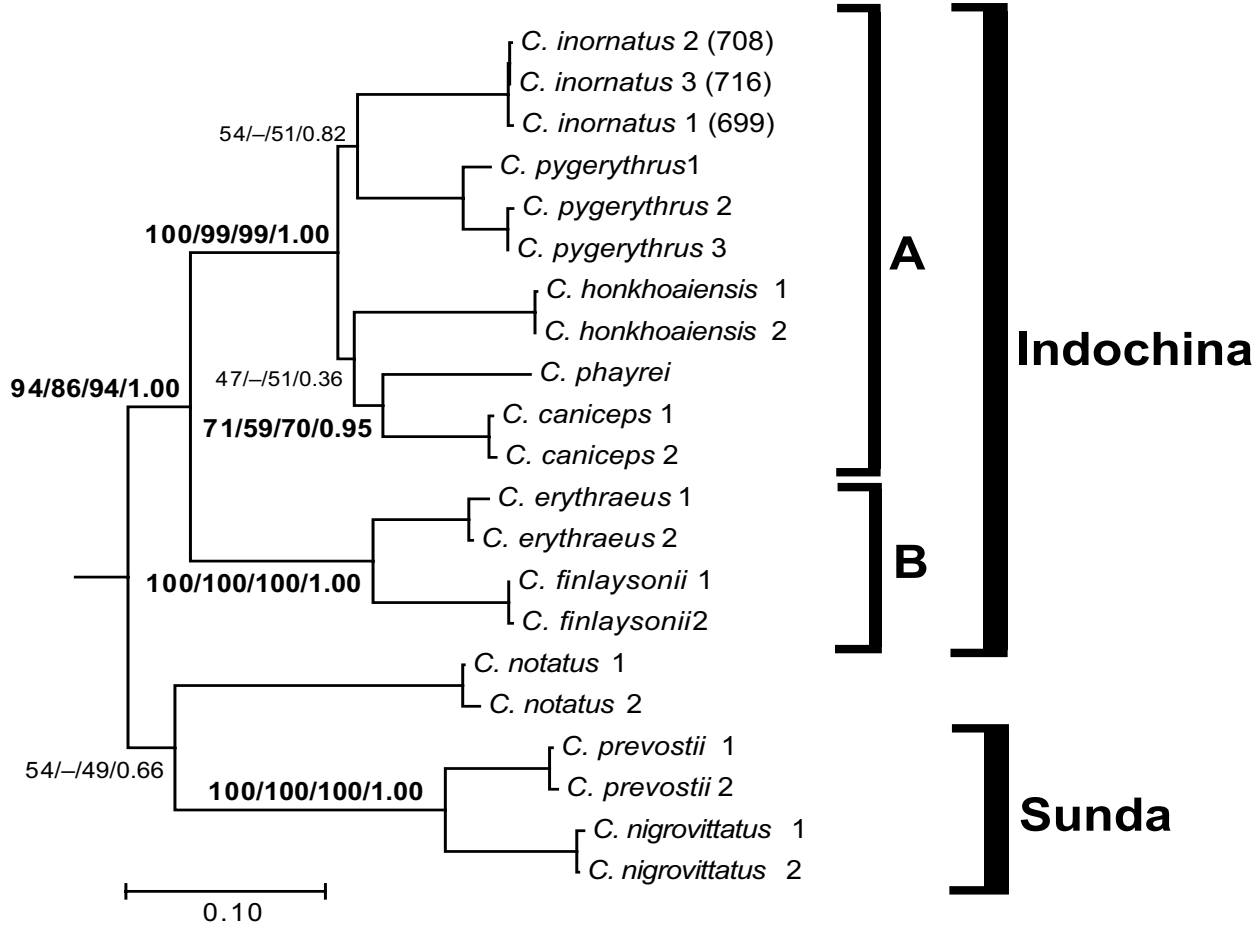

Fig. 2. Phylogeny of Callosciurus constructed with the maximum-likelihood (ML) under $\mathrm{HKY}+\mathrm{I}+\Gamma$ model for cytochrome $b$ sequences. From left, numbers above branches represent: bootstrap values from 1000 replicates of ML and un-weighted maximum parsimony (MP) analyses, bootstrap values from 5000 replicates of neighbor-joining (NJ) analysis and posterior probability supports in Bayesian analysis. Hyphens mean no data, because the clade was absent 
honkhoaiensis and C. phayrei, but these were not reliably supported. Callosciurus phayrei was closely related to $C$. caniceps, although support values were not high $(71 \%, 59 \%, 70 \%$ and 0.95 in the ML, MP, NJ and BI trees, respectively).

The divergence time estimates are shown in Figure 3. In the Indochina lineage, the divergence time between lineages $\mathrm{A}$ and $\mathrm{B}$ was estimated to be 3.73 Ma; while within lineage A, the divergence between the two sub-lineages was estimated to be $2.19 \mathrm{Ma}$. The estimated divergence time between $C$. honkhoaiensis and the ancestor of $C$. caniceps and C. phayrei was $1.96 \mathrm{Ma}$, and that between $C$. caniceps and $C$. phayrei was $1.76 \mathrm{Ma}$. Besides, the divergence time between C. inornatus and C. pygerythus was estimated to be 1.95 Ma.
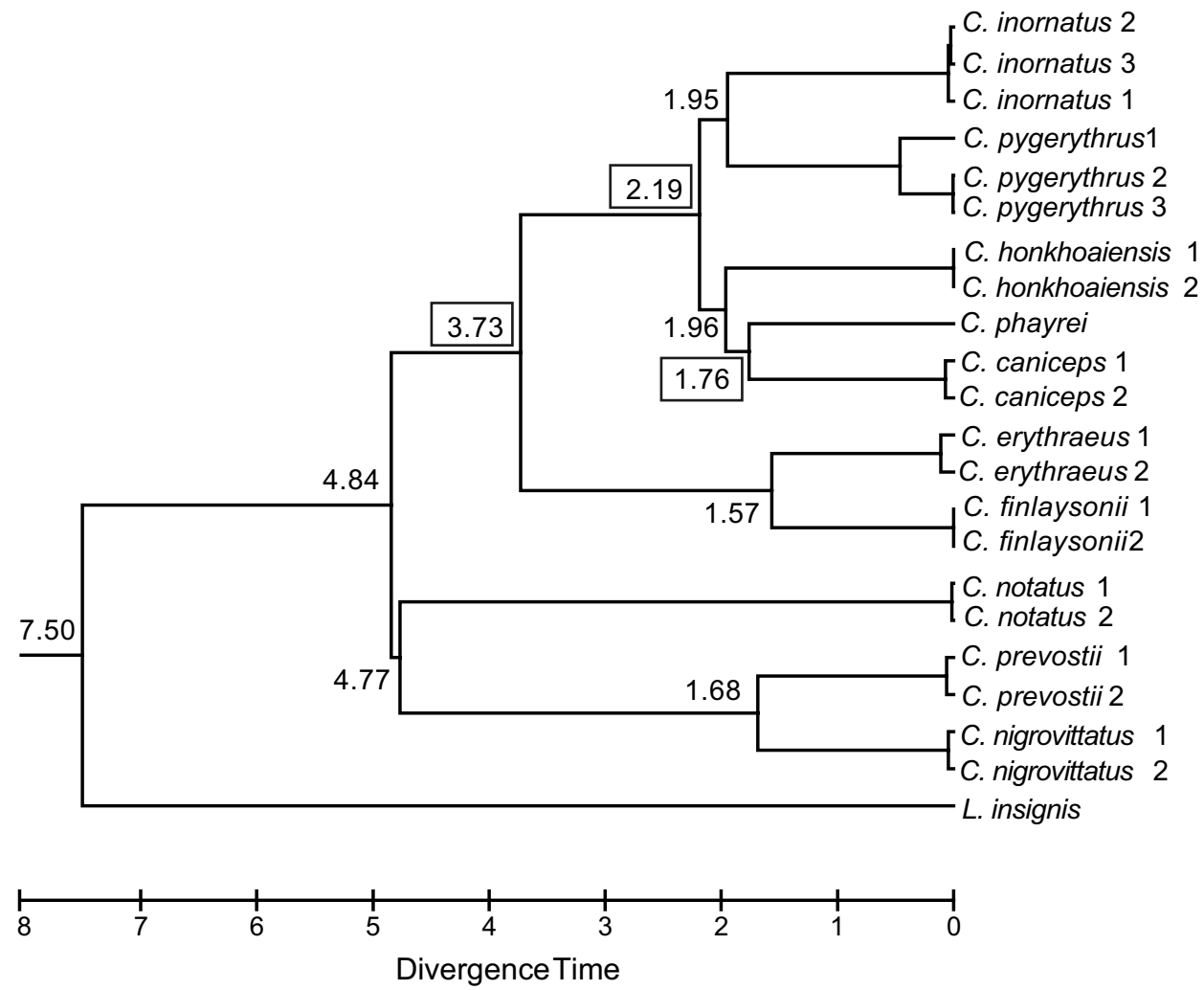

Fig. 3. Divergence time tree estimated by the RelTime method, based on the maximumlikelihood (ML) analysis under HKY $+\mathrm{I}+\Gamma$ model for the cytochrome $b$ sequences. Divergence times among Callosciurus squirrels in millions of years before present are on branches. Divergence times with high support values are inside squares 


\section{DISCUSSION}

Recently, BoonkHaw et al. (2017) described two Callosciurus linages from the Indochina Peninsula: one containing C. caniceps, C. inornatus and C. phayrei and the other containing C. erythraeus and C. finlaysonii. We observed two major lineages: lineages A comprising C. caniceps, C. inornatus, C. phayrei, C. pygerythrus and C. honkhoaiensis and B comprising C.erythraeus and C. finlaysonii, thus adding $C$. pygerythrus and $C$. honkhoaiensis to the first lineage described by BoonkHAw et al. (2017). The estimated divergence time (about $3.73 \mathrm{Ma}$ ) between lineages A and B was at the junction of the Zanclean and Piacenzian in the Pliocene. Drastic divergence of shrews (Dubey et al. 2008, Esselstyn et al. 2009, Yuan et al. 2013) and murine rodents (Ruedas \& Kirsch 1997, Gorog et al. 2004) are also found in the Indochina Peninsula during the early Pliocene. Sediment core data suggest that global climatic conditions were altered in the early and middle Pliocene (Kashiwaya et al. 2001), with global cooling in the late Pliocene (RAvelo et al. 2004, Haywood et al. 2009). This suggests a potential role of climate conditions in the divergence of two lineages A and B.

Phylogenetic relationships within lineage A were unclear because of lower support values (Fig. 2). The estimated divergence times among these five species (about 2.19 Ma) correspond to the Pliocene-Pleistocene boundary, which experienced a cooler global climate (RAvelo et al. 2004, Haywood et al. 2009). Climatic change is known to affect the distribution of forests in the Northern Hemisphere (e.g. Heuertz et al. 2010, Stefenon et al. 2019), and these changes in forest environments could thereby affect arboreal Callosciurus squirrels.

The estimated divergence time between $C$. caniceps and $C$. phayrei was about 1.76 Ma, which lies at the junction of the Calabrian and Gelasian. In the 1.8-1.2 Ma interval, a decrease in global temperatures increased the specialization of mammal species and the fauna adapted to cooler environments (KAhlKe et al. 2011). For instance, in the Gelasian/Calabrian translation in Italy, fossils of extinct ungulates show an abundance of mixed feeders (such as Leptobos etruscus, Pseudodama nestii and Stephanorhinus etruscus) and grazers (such as Equus stenonis and Gazella meneghini) and a lack of browsers, indicating the development of open grasslands and open woodlands (STRANi et al. 2018). The ancestral form of these two Callosciurus species may have been affected by similar climatological alteration in the peninsula.

We found that C. pygerythrus was included in caniceps-honkhoaiensis-inornatus-phayrei lineage reported previously (BoonkHAw et al. 2017, NGUYEN et al. 2018), but it was difficult to explain the evolutionary history within this lineage. Each Callosciurus species of this lineage also exhibits wide regional variation (CоRbet \& Hill 1992, Thorington et al. 2012, Koprowski et al. 2016). Therefore, to better understand the evolutionary history of this lineage, future 
studies need to analyze the relationships among regional forms (subspecies) of each species, similar to the works of BoonKHAW et al. (2017) and BALAKIREV and Rozhnov (2019) on the C. erythraeus/finlaysonii complex.

Acknowledgements - We thank C. L. Bridgman for her critical reading of the manuscript. This study was partly supported by the Grants-in-Aid for Scientific Research Nos. 26304009 and 18H03602 from the Ministry of Education, Science, Sports, and Culture, Japan.

\section{REFERENCES}

Balakirev, A. E. \& Rozhnov, V. V. (2019): Taxonomic revision of beautiful squirrels (Callosciurus, Rodentia: Sciuridae) from the Callosciurus erythraeus/finlaysonii complex and their distribution in eastern Indochina. - Raffles Bulletin of Zoology 67: 459-489. https://doi.org/10.26107/RBZ-2019-0037

Boonkhaw, P., Prayoon, U., Kanchanasaka, B., Hayashi, F. \& Tamura, N. (2017): Colour polymorphism and genetic relationships among twelve subspecies of Callosciurus finlaysonii in Thailand. - Mammalian Biology 85: 6-13. https://doi.org/10.1016/j.mambio.2017.02001

Corbet, G. B. \& Hill, J. E. (1992): The mammals of the Indomalayan region: a systematic review. - Oxford University Press, Oxford, 488 pp.

Cox, C. B. \& Moore, P. D. (2005): Biogeography: an ecological and evolutionary approach. 7th ed. - Blackwell Publishing Ltd, Oxford, 428 pp.

Dubey, S. N., Salamin, N., Ruedi, M., Barrière, P., Colyn, M. \& Vogel, P. (2008): Biogeographic origin and radiation of the Old World crocidurine shrews (Mammalia: Soricidae) inferred from mitochondrial and nuclear genes. - Molecular Phylogenetics and Evolution 48: 953-963. https://doi.org/10.1016/j.ympev.2008.07.002

Ellerman, J. R. \& Morrison-Scott, T. C. S. (1966): Checklist of Palaearctic and Indian mammals, 1758 to 1946. 2nd ed. - British Museum (Natural History), London, 810 pp.

Esselstyn, J. A., Timm, R. M. \& Brown, R. M. (2009): Do geological or climatic processes drive speciation in dynamic archipelagos? The tempo and mode of diversification in Southeast Asian shrews. - Evolution 63: 2595-2610. https://doi.org/10.1111/j.15585646.2009.00743.x

Felsenstein, J. (1985): Confidence limits on phylogenies: an approach using the bootstrap. - Evolution 39: 783-791. https://doi.org/10.1111/j.1558-5646.1985.tb00420.x

Gorog, A. J., Sinaga, M. H. \& Engstrom, M. D. (2004): Vicariance or dispersal? Historical biogeography of three Sunda shelf murine rodents (Maxomys surifer, Leopoldamys sabanus and Maxomys whiteheadi). - Biological Journal of the Linnean Society 81: 91109. https://doi.org/10.1111/j.1095-8312.2004.00281.x

Groves, C. P. (2005): Order primates. Pp. 111-184. In: Wilson, D. E. \& Reeder, D. M. (eds): Mammal species of the world: A taxonomic and geographic references, 3rd ed., Vol. 2. Johns Hopkins University Press, Baltimore.

Grubb, P. (2005): Order Artiodactyla. Pp. 637-722. In: Wilson, D. E. \& Reeder, D. M. (eds): Mammal species of the world: A taxonomic and geographic references, 3rd ed. Vol. 2. Johns Hopkins University Press, Baltimore. 
Hasegawa, M., Kishino, H. \& Yano, T. (1985): Dating of the human-ape splitting by a molecular clock of mitochondrial DNA. - Journal of Molecular Evolution 22: 160-174. https://doi.org/10.1007/BF02101694

Haywood, A. M., Dowsett, H. J., Valdes, P. J., Lunt, D. J., Francis, J. E. \& Sellwood, B. W. (2009): Introduction. Pliocene climate, processes and problems. - Philosophical Transactions of the Royal Society A 367: 3-17. https://doi.org/10.1098/rsta.2008.0205

Heuertz, M., Teufel, J., González-Martínez, S. C., Soto, A., Fady, B., Alía, R., Vendramin, G. G. \& Linder, P. (2010): Geography determines genetic relationships between species of mountain pine (Pinus mugo complex) in western Europe. - Journal of Biogeography 37: 541-556. https://doi.org/10.1111/j.1365-2699.2009.02223.x

Kahlke, R-D., García, N., Kostopoulos, D. S., Lacombat, F., Lister, A. M., Mazza, P. P. A., Spassov, N. \& Titov, V. V. (2011): Western Palearctic palaeoenvironmental conditions during the Early and early Middle Pleistocene inferred from large mammal communities, and implications for hominin dispersal in Europe. - Quaternary Science Reviews 30: 1368-1395. https://doi.org/10.1016/j.quascirev.2010.07.020

Kashiwaya, K., Ochiai, S., Sakai, H. \& KawaI, T. (2001): Orbit-related long-term climate cycles revealed in a 12-myr continental record from Lake Baikal. - Nature 410: 71-74. https://doi.org/10.1038/35065057

Kimura, M. (1980): A simple method for estimating evolutionary rates of base substitutions through comparative studies of nucleotide sequences. - Journal of Molecular Evolution 16: 111-120. https://doi.org/10.1007/BF01731581

Kocher, T. D., Thomas, W. K., Meyer, A., Edwards, S. V., Paabo, S., Villablanca, F. X. \& Wilson, A. C. (1989): Dynamics of mitochondrial DNA evolution in animals: amplification and sequencing with conserved primers. - Proceedings of the National Academy of Sciences of the United States of America 86: 6196-6200. https://doi.org/10.1073/pnas.86.16.6196

Koprowski, J. L., Goldstein, E. A., Bennett, K. R. \& Mendes, C. P. (2016): Family Sciuridae (tree, flying and ground squirrels, chipmunks, marmots and prairie dogs). Pp. 648-837. In: Wilson, D. E., Lacher Jr, T. E. \& Mittermeier, R. A. (eds): Handbook of the mammals of the world 6: Lagomorphs and Rodents I. - Lynx Edicions, Barcelona.

Kumar, S., Stecher, G. \& Tamura, K. (2016): MEGA7: molecular evolutionary genetics analysis version 7.0 for bigger datasets. - Molecular Biology and Evolution 33: 18701874. https://doi.org/10.1093/molbev/msw054

MacKinnon, K., Hatta, G., Halim, H. \& Mangalic, A. (1996): The ecology of Kalimantan: Indonesian Borneo. - Periplus Editions Ltd, Singapore, 802 pp.

MeijaArd, E. \& Groves, C. P. (2006): The geography of mammals and rivers in mainland Southeast Asia. Pp. 305-329. In: Lehman, S. M. \& Fleagle, J. G. (eds): Primate biogeography. - Springer Science + Business Media, LLC, New York. https://doi.org/10.1007/0387-31710-4_11

Mercer, J. M. \& Roth, V. L. (2003): The effects of Cenozoic global change on squirrel phylogeny. - Science 299: 1568-1572. https://doi.org/10.1126/science.1079705

Mittermeier, R. A., Turner, W. R., Larsen, F. W., Brooks, T. M. \& Cascon, C. (2011): Global biodiversity conservation: the critical role of hotspots. Pp. 3-22. In: ZACHOs, F. E. \& HABEL, J. C. (eds): Biodiversity hotspots: distribution and protection of conservation priority areas. - Springer Verlag, Berlin. https://doi.org/10.1007/978-3-642-20992-5_1

Nguyen, S. T., Görföl, T., Francis, C. M., Мotokawa, M., Estók, P., Endo, H., Vu, T. D., Nguyen, D. X., Oshida, T. \& Csorba, G. (2013): Description of a new species of Myotis (Vespertilionidae) from Vietnam. - Acta Chiropterologica 15: 473-483. https://doi. org/10.3161/150811013X679099 
Nguyen, S. T., Motokawa, M., Oshida, T., Vu, T. D., Csorba, G. \& Endo, H. (2015): A new species of the genus Murina (Chiroptera: Vespertilionidae) from the central highlands of Vietnam with a review of the subfamily Murininae in Vietnam. - Acta Chiropterologica 17: 201-232. https://doi.org/10.3161/15081109ACC2015.17.2.001

Nguyen, S. T., Oshida, T., Dang, P. H., Bui, H. T. \& Motokawa, H. (2018): A new species of squirrel (Sciuridae: Callosciurus) from an isolated island off the Indochina Peninsula in southern Vietnam. - Journal of Mammalogy 99: 813-825. https://doi.org/10.1093/ jmammal/gyy061

Oshida, T., Dang, C. N., Nguyen, S. T., Nguyen, N. X., Endo, H., Kimura, J., Sasaki, M., Hayashida, A., Takano, A., Yasuda, M. \& Hayashi, Y. (2011): Phylogenetic relationship between Callosciurus caniceps and C. inornatus (Rodentia, Sciuridae): implications for zoogeographical isolation by the Mekong River. - Italian Journal of Zoology 78: 328-335. https://doi.org/10.1080/11250003.2010.490566

Oshida, T., Dang, C. N., Nguyen, S. T., Nguyen, N. X., Endo, H., Kimura, J., Sasaki, M., Hayashida, A., Takano, A., Koyabu, D. \& Hayashi, Y. (2013): Phylogenetic position of Callosciurus erythraeus griseimanus from Vietnam in the genus Callosciurus. Mammal Study 38: 41-47. https://doi.org/10.3106/041.038.0105

Oshida, T., Lin, L-K., Masuda, R. \& Yoshida, M. C. (2000): Phylogenetic relationships among Asian species of Petaurista (Rodentia, Sciuridae) inferred from mitochondrial cytochrome b gene sequences. - Zoological Science 17: 123 - 128. https://doi. org/10.2108/zsj.17.123

Oshida, T., Yasuda, M., Endo, H., Hussein, N. A. \& Masuda, R. (2001): Molecular phylogeny of five squirrel species of the genus Callosciurus (Mammalia, Rodentia) inferred from cytochrome b gene sequences. - Mammalia 65: 473-482. https://doi.org/10.1515/ mamm.2001.65.4.473

Oshida, T., YAsuda, M. \& SASAKI, M. (2016): Preliminary study on phylogeography of Callosciurus prevostii in Southeast Asia: mitochondrial DNA evidence supports riverine barrier hypothesis. - Mammal Study 41: 149-154. https://doi.org/10.3106/041.041.0305

Ravelo, A. C., Andreasen, D. H., Lyle, M., Lyle, A. O. \& Wara, M. W. (2004): Regional climate shifts caused by gradual global cooling in the Pliocene epoch. - Nature 429: 263-267. https://doi.org/10.1038/nature02567

Ruedas, L. A. \& Kirsch, J. A. W. (1997): Systematics of Maxomys Sody, 1936 (Rodentia: Muridae: Murinae): DNA/DNA hybridization studies of some Borneo-Javan species and allied Sundaic and Australo-Papuan genera. - Biological Journal of the Linnean Society 61: 385-408. https://doi.org/10.1111/j.1095-8312.1997.tb01798.x

SAitou, N. \& NeI, M. (1987): The neighbor-joining method: a new method for reconstructing phylogenetic trees. - Molecular Biology and Evolution 4: 406-425. https://doi. org/10.1093/oxfordjournals.molbev.a040454

Salo, J., Kalliola, R., Häkkinen, I., Mäkinen, Y., Niemelä, P., Puhakka, M. \& Coley, P. D. (1986): River dynamics and the diversity of Amazon lowland forest. - Nature 322: 254-258. https://doi.org/10.1038/322254a0

Stefenon, V. M., Klabunde, G., Lemos, R. P. M., Rogalski, M. \& Nodari, R. O. (2019): Phylogeography of plastid DNA sequences suggests post-glacial southward demographic expansion and the existence of several glacial refugia for Araucaria angustifolia. - Scientific Reports 9: 2752. http://doi.org/10.1038/s41598-019-39308-w

Strani, F., DeMiguel, D., Bellucci, L. \& Sardella, R. (2018): Dietary response of early Pleistocene ungulate communities to the climate oscillations of the Gelasian/Calabrian transition in Central Italy. - Palaeogeography, Palaeoclimatology E Palaeoecology 499: 102-111. https://doi.org/10.1016/j.palaeo.2018.03.021 
Suchard, M. A., Lemey, P., Baele, G., Ayres, D. L., Drummond, A. J. \& Rambaut, A. (2018): Bayesian phylogenetic and phylodynamic data integration using BEAST 1.10. - Virus Evolution 4: vey016. https://doi.org/10.1093/ve/vey016

Tamura, K., Battistuzzi, F. U., Billing-Ross, P., Murillo, O., Filipski, A. \& Kumar, S. (2012): Estimating divergence times in large molecular phylogenies. - Proceedings of the National Academy Sciences of the United States of America 109: 19333-19338. https:// doi.org/10.1073/pnas.1213199109

Thorington, R. W. \& Hoffmann, R. S. (2005): Family Sciuridae. Pp. 754-818. In: Wilson, D. E. \& REeDer, D. M. (eds): Mammal species of the world: a taxonomic and geographic references. 3rd ed. Vol. 2. - Johns Hopkins University Press, Baltimore.

Thorington, R. W., Koprowski, J. L., Steele, M. A. \& Whatton, J. F. (2012): Squirrels of the world. - Johns Hopkins University Press, Baltimore, 459 pp.

Yuan, S-L., Jiang, X-L., Li, Z-J., He, K., Harada, M., Oshida, T. \& Lin, L-K. (2013): A mitochondrial phylogeny and biogeographical scenario for Asiatic water shrews of the genus Chimarrogale: implications for taxonomy and low-latitude migration routes. - Plos One 8(10): e77156. https://doi.org/10.1371/journal.pone.0077156

Received August 27, 2020, accepted December 3, 2021, published February 22, 2021 